\title{
NEW CANADIAN FIRE RESEARCH LABORATORY
}

\author{
By R. F. LEGGET
}

Director, Division of Building Research, National Research Council of Canada

$\mathrm{F}^{\mathrm{n}}$ RE research in Canada advanced significantly with the opening on October 3 of the new Fire Research Laboratory of the National Research Council of Canada at Ottawa. The new building forms part of the Building Research Centre of the Council's Division of Building Research. It is situated on the extensive property of the Council known as the Montreal Road Laboratories, an area of about 400 acres in which the three engineering research divisions of the National Research Council and some other Council establishments are situated.

The official opening of the building was performed by Dr. F. M. Lea, director of the British Building Research Station, assisted by Mr. Dennis Lawson, the newly appointed director of the British Joint Fire Research Organization, both of whom had come to Ottawa especially for the occasion. The Canadian Division of Building Research has close liaison with both these British research organizations, the debt to which in the development of its work and in the planning of the new building was acknowledged by the director during the opening ceremony.

The opening of the new building followed a twoday conference on fire research and fire prevention, at which statements were presented regarding the work of all the major fire-prevention agencies of Canada. Speakers from the United States, Britain and Canada gave a review of fire research throughout the world. Some details of Canadian fire research were givon to the conference, including preliminary results from full-scale burns of eight buildings in the small town of Aultsville, abandoned because of flooding caused by the construction of the international power dam on the St. Lawrence.

The fire research building (Fig. 1) has basically the shape of a large $T$, with offices and laboratories in the front wing, and the large furnace laboratory and a burn area for model studies in the rear wing. One-story additions have been erected on either side of the furnace laboratory to provide storage and workshop facilities, garage space for the station wagon used in field investigations, a control room for the operation of the fire-resistance furnaces, and additional laboratory facilities for hydraulic testing.

The building covers an area of $20,000 \mathrm{sq}$. ft. and has a total volume of more than $550,000 \mathrm{cu}$. ft., of which nearly half is made up of the volume of the 40-ft. high structure housing the furnace laboratory and the burn area. The total contract price, including all extras, which amounted to less than 4 per cent of the original cost, was 820,000 dollars, or a cost per cubic foot of less than 1.50 dollars.

The building, founded throughout on solid rock, consists of a structural steel frame supported on reinforced concrete. The outside walls, built of structural clay tile, are finished with stucco on metal lath on the outside and with glazed tile on the inside.

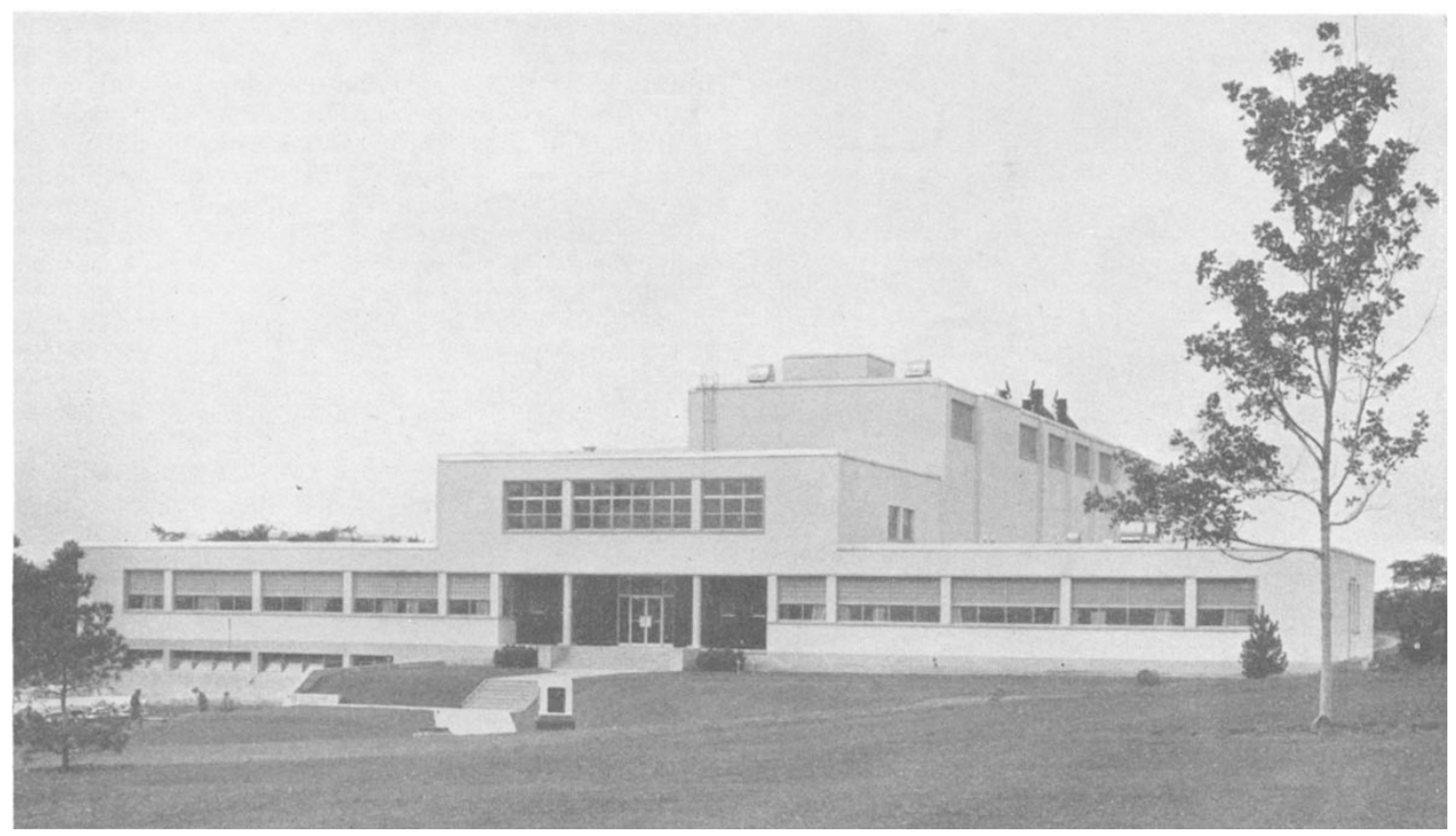

(Thotograph : National Film Board of Canada)

Fig. 1. Fire Research Building of the Division of Building Research, National Research Couneil, ottawa 
The area to the rear of the Fire Research Building was the site of an old quarry. Its rocky floor, which is approximately $5-10 \mathrm{ft}$. below the level of the surrounding area, provides an excellent outdoor experimental site on which to conduct large-scale tests on extinguishing fires.

The fire-resistance test facilities consist of two furnaces, complete with auxiliary equipment, together with the associated facilities for constructing, handling, conditioning and disposing of large test specimens. The design of the special facilities contained in the laboratory was carried out concurrently with the design and construction of the building itself, by a separate firm of consultants, Ewbank and Partners (Canada), Ltd., working in co-operation with the architects and engineers for the building.

The wall furnace (Fig. 2) consists essentially of a movable burner assembly open at the front, with the burners situated in the rear wall of the unit. The combustion chamber is completed when the front face of the burner assembly is fixed to the specimen under test. In this position the top of the furnace is immediately under the flue used for removing the combustion gases.

The size of the specimen exposed to the combustion chamber is $12 \mathrm{ft}$. by $12 \mathrm{ft}$., although the loading frame itself will accommodate a specimen $14 \mathrm{ft}$. by $14 \mathrm{ft}$. The heat in the combustion chamber is supplied by 100 burners having a capacity of $50 \mathrm{cu}$. ft. of gas per hour at a pressure of $25 \mathrm{lb}$./in. ${ }^{2}$. The fuel used is propane, having a gross heating value of approximately 2,500 B.T.U./cu. ft. ; thus the maximum total heat input is approximately $12,500,000$ B.T.U./hr.

The floor furnace (Fig. 3), in contrast to the wall furnace, is a fixed installation. The burners are installed in the two long sides and the two flues are permanently connected to the common flue used for

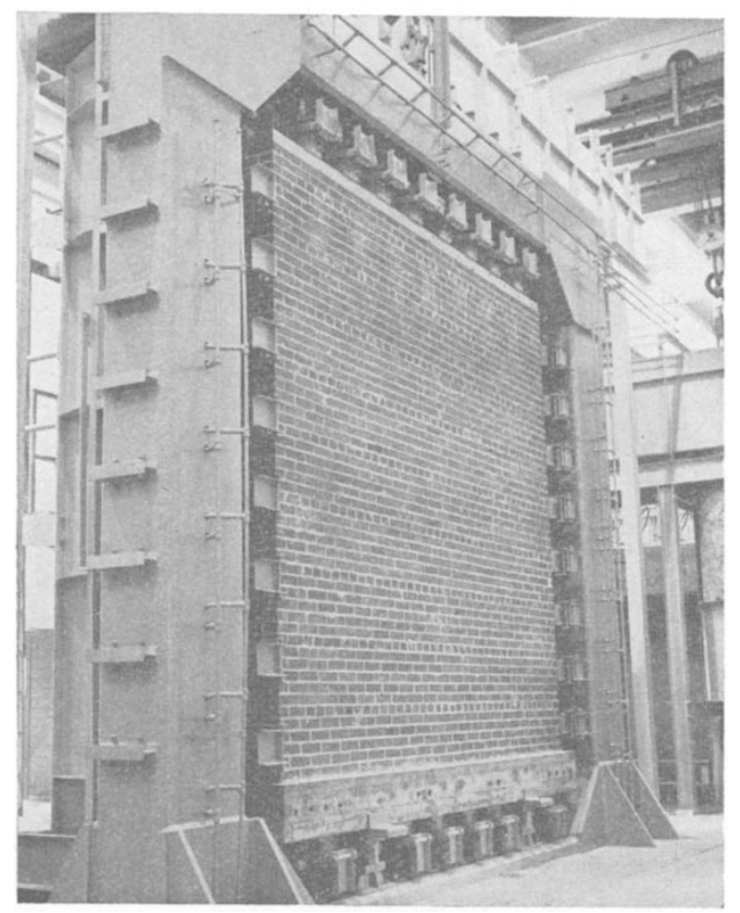

(Photograph : National Film Board of Canada)

Fig. 2. Loading frame with wall specimen in wall furnace in the furnace laboratory

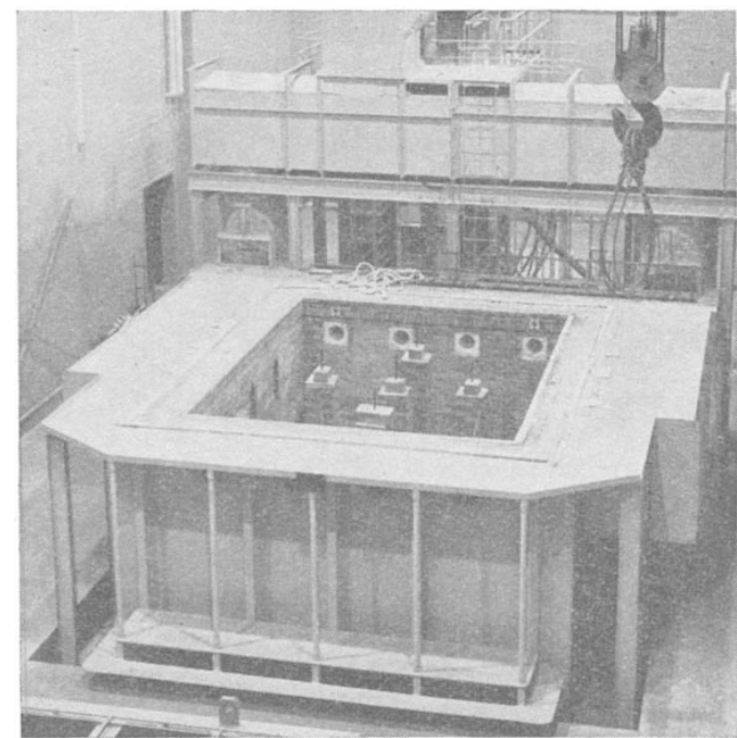

(Photograph : National Film Board of Canada)

Fig. 3. Floor furnace in the furnace laboratory

conducting the flue gases from the building. The combustion chamber is completed when the specimen is laid on top of the furnace.

The furnace at present will allow a floor specimen to have an area of $12 \mathrm{ft}$. by $15 \mathrm{ft}$. exposed to heat. When using this furnace for testing beams it will be possible to extend a beam past the furnace wall and load this portion of the beam as well.

Heat is supplied by means of thirty burners (fifteen on each side), each burner having a capacity of $220 \mathrm{cu}$. ft. of gas per hour at a pressure of $25 \mathrm{lb}$./in. 2 . As in the case of the wall furnace, propane will be the fuel, so that the gross heat input is approximately $16,500,000$ B.T.U./hr.

Liquid propane is stored in a 1,750-gallon tank situated outside the building. When operating the furnaces, the liquid is passed through three vaporizers, each capable of vaporizing 70 gallons of propane per hour at $25 \mathrm{lb}$./in. ${ }^{2}$. The gas is then piped underground. in a 4-in. pipe to the building. Inside the building the propane then passes through a diaphragm motor control valve, which closes if there is a failure of the control air. There is a pilot flame by-pass valve in the line before the motor control valve, and two shut-off gas cocks immediately after this valve direct the flow either to the floor or to the wall furnace. The wall furnace has ten banks of burners with ten burners in each bank, while the floor furnace has five banks of three burners each on each side. Each group of three burners is fitted with a solenoidactuated shut-off valve and pressure gauge.

The combustion control for both of the furnaces is furnished by a potentiometric temperature-programme controller which follows the time-temperature curve designated in the current U.S. Standard (ASTM E119-57, Standard Methods of Fire Tests of Building Construction and Materials).

The two large furnaces will be put to use immediately for carrying out tests upon the fire-resistance of building materials in current use in Canada. These tests must be done since the furnaces are unique in Canada, but they involve an element of research, and the furnaces will be used for research investigations whenever possible. In the laboratories, 
studies will continue on the properties of foam as an extinguisher of fire, into the problems of radiation from fire and on more detailed questions such as those related to the burning characteristics of materials. The results of all work will be made available to the committees responsible for the National Building Code of Canada for incorporation into successive revisions. The Code is an advisory document pub- lished by the National Research Council of Canada, and has legal effect only when adopted by municipalities for their own local use. It is already in legal use in this way for well over one-third of the population of Canada. As its adoption spreads, the results of the fire research programme will therefore be of direct effect to a large proportion of the people of the Dominion.

\section{CHANGING INDUSTRY}

$\mathrm{T}$ HERE are clear signs that the post-war period of steady expansion is coming to an end. European competition is increasing, and there is a formidable growth of productive capacity in every continent. Apparent over-capacity in industry, the coming of nuclear power, international shortage of capital and low raw material prices are all con. tributing to a readjustment of the world's economy and are posing a direct challenge to British management.

This was the theme of the national conference of the British Institute of Management which was held at Brighton during November 26-28, 1958. The variety of papers presented by many distinguished speakers gave the hundreds of delegates considerable choice of meetings to attend; this is one of the admirable features of the Institute's conference which commends it to so many members but also makes it impossible to describe adequately. In two days there were twenty-three separate meetings and at least twenty-five study groups at which the topics ranged from staff assessment and grading to the best use of scientists in industry, the balance between technological education and management education and the problems of accounting in large multi-unit undertakings.

In the opening address Sir Harold Howitt, one of the three members of the Council on Prices, Productivity and Incomes, emphasized that the chief challenge facing management is inflation. So-called creeping inflation with its cumulative effects may soon become galloping inflation and get out of hand. But it is no use paying lip service to the desirability of killing inflation unless one is prepared to take the medicine that is involved in the process. Nor is it any use putting all the blame for inflation on one or other section of the community or expecting it to take all the medicine. All must exercise restraint. Wage increases are not harmful if they keep within the increase in productivity, since prices can then remain stable and the increase in wages will have been real. In the industrial field as a whole, total profits after depreciation from 1950 to 1956 have been about one-third as much as wages and salaries ; profits must bear their share of responsibility for inflation.

One of the most important contributions to the conference was made by Griffith Page, managing director of the National Union of Manufacturers Advisory Service, Ltd., who described the ways in which small firms were being helped towards greater efficiency. Five years ago the Union was set up as a department of the National Union of Manufacturers, with financial aid under the Conditional Aid Scheme, and with emphasis on management and production organization. The lines along which the service developed were decided by the nature of the problems presented by the firms who sought its aid, by conviction that efforts and resources should be directed towards making the maximum possible impact in terms of productivity and efficiency upon the general population of small firms, and by the necessity to make the service self-supporting.

The natural interest of the membership of the National Union of Manufacturers and occasional Press reports have been adequate to generate a flow of inquiries, the follow-up of which has kept a growing staff fully engaged.

Altogether, some five hundred firms, representative of a wide cross-section of the smaller firms, have used the service, and the Union's Advisory Service has been able to acquire an increasingly intimate understanding of the financial pattern, the management structure, the production organization and the problems of small firms. Although the promotion of work study as a principal ageney for promoting higher productivity held, and does still hold, an important place among the objectives of the Advisory Service, it was necessary to take a wider view of the management problems in small firms. This led to the adoption of a survey technique which approximates to the American concept of the management audit. Such surveys involve an appraisal of the overall business position of a company, its industrial standing, its policy and objectives, financial position, management structure, sales organization and productive efficiency. Their purpose is to enable the National Union of Manufacturers Advisory Service, Ltd., to indicate in what directions companies can most beneficially take action to improve their prosperity and well-being.

After such a survey, recommendations are made, and these may cover any one or a number of areas of management responsibility. The firm may be advised to install one or other of the principal management techniques, of which work study is predominant, because it usually provides the necessary foundation for others, like production control and standard costing. The introduction of work study is one which requires an appreciable period of full-time assistance, and the Advisory Service staff of industrial engineers is available to shoulder the main responsibility for its introduction and to train members of the firm's own staff so that the schemes introduced shall be properly maintained. The Advisory Service seeks to assess the limitations and the potentialities of the smaller firms in the total business sense, to explain how sound prineiples of management and modern techniques of management can be applied in the context of their own highly individual situations, to indicate the advantages which can flow from their adoption and, in so far as it is necessary to ensure that this is adequately 